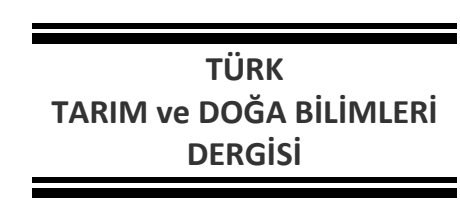

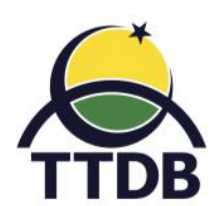

www.dergipark.gov.tr/turkjans

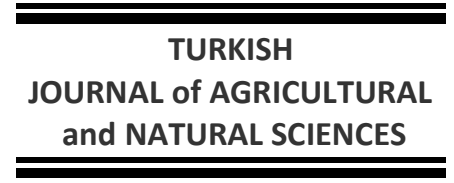

Research Article

\title{
Assessment of Biomarkers of Oxidative Stress and Antioxidant in Wild and Farmed Çoruh trout (Salmo coruhensis) Spermatozoa
}

\author{
Mehmet KOCABAŞ ${ }^{1}$, Filiz KUTLUYER ${ }^{2 *}$, Fulya BENZER ${ }^{3}$, Mine ERişiR ${ }^{4}$ \\ ${ }^{1}$ Karadeniz Technical University, Faculty of Forestry, Department of Wildlife Ecology \& Management, Trabzon, \\ TURKEY \\ ${ }^{2}$ Munzur University, Fisheries Faculty, Tunceli, TURKEY \\ ${ }^{3}$ Munzur University, Faculty of Engineering, Department of Food Engineering, Tunceli, TURKEY \\ ${ }^{4}$ FIrat University, Faculty of Veterinary, Department of Basic Sciences, Elazığ, TURKEY \\ *Corresponding author: filizkutluyer@hotmail.com
}

Received: 07.11.2018

Received in Revised: 14.02.2019

Accepted: 12.03 .2019

\begin{abstract}
Behaviour and physiology in fish are affected from environmental factors. Particularly, habitat and culture environment in aquatic animals are essential for life stages. In this study, biomarkers of oxidative stress and antioxidant were compared in wild and farmed Çoruh trout (Salmo coruhensis) spermatozoa. In spermatozoa of Çoruh trout, lipid peroxidation (malondialdehyde), glutathione and enzymatic antioxidant activities (catalase, superoxide dismutase, glutathione peroxidase) were assessed. Our data demonstrated that superoxide dismutase $\left(0.44 \pm 1.25 \mathrm{Umg}^{-1}\right.$ protein), catalase $\left(15.21 \pm 4.69 \mathrm{k.g}^{-1}\right.$ protein), glutathione peroxidase $\left(42.89 \pm 0.61 \mathrm{Ug}^{-}\right.$ ${ }^{1}$ protein), glutathione $\left(0.18 \pm 4.01 \mu^{m o l g}{ }^{-1}\right.$ cell) and malondialdehyde $\left(2.49 \pm 0.12 \mathrm{nmol} . \mathrm{g}^{-1}\right.$ cell) levels in wild fish were low compared to spermatozoa of farmed fish. Overall, alterations in malondialdehyde levels and the antioxidant status could be differences in habitat.
\end{abstract}

Key words: Antioxidant Status, Çoruh trout, oxidant status, Salmo coruhensis, spermatozoa.

\section{Doğada ve Kültür Ortamındaki Çoruh alabalığı (Salmo coruhensis) Spermatozoasının Oksidatif Stres ve Antioksidan Biyobelirteçlerinin Belirlenmesi}

\begin{abstract}
Özet
Balıklarda davranış ve fizyoloji çevresel faktörlerden etkilenmektedir. Özellikle, kültür ortamı ve habitat sucul canlıların yaşam safhaları için önemlidir. Bu çalışmada, doğadaki ve çiftlik ortamındaki balıkların spermatozoasındaki oksidatif stres ve antioksidan biyomarkırları karşılaştırılmıştır. Çoruh alabalığının (Salmo coruhensis) spermatozasında enzimatik antioksidan aktiviteleri (süperoksit dismutaz, katalaz, glutatyon peroksidaz), glutatyon ve lipid peroksidasyonu (malondialdehit) belirlenmiştir. Sonuçlar süperoksit dismutaz (0.44 $\pm 1.25 \mathrm{Umg}^{-1}$ protein), katalaz (15.21 $\pm 4.69 \mathrm{k.g}^{-1}$ protein), glutatyon peroksidaz $42.89 \pm 0.61 \mathrm{Ug}^{-1}$ protein), glutatyon $\left(0.18 \pm 4.01 \mathrm{\mu molg}^{-1}\right.$ hücre) ve malondialdehit $\left(2.49 \pm 0.12 \mathrm{nmolg}^{-1}\right.$ hücre) seviyelerinin kültür ortamındakilerle karşılaştırıldığında doğadaki balık spermatozoasında düşük olduğunu göstermiştir. Sonuç olarak, habitattaki farklılıklar antioksidan durumu ve malondialdehit seviyelerinde değişikliklere neden olabilir.
\end{abstract}

Anahtar kelimeler: Antioksidan durum, Çoruh alabalığı, oksidan durum, Salmo coruhensis, spermatozoa.

\section{Introduction}

Salmo trutta being Salmonid fish species has aquaculture potential, economic and recreational value (Kocabas et al., 2011a;b). Distribution of its forms is occurred from in Europe, North Africa,
West Asia to Anatolia (Kuru, 2004; Kottelat and Freyhof, 2007Li). Black Sea trout (S. t. labrax) has been identified by Turan et al. (2009) as Salmo coruhensis (Can et al., 2012; Seyhaneyildiz Can et al., 2014). An endemic anadromus fish S. coruhensis 
is only presented in the rivers and streams of Eastern Black Sea Region (Kocabaş and Bascinar, 2013).

Generation of reactive oxygen species (ROS) is affected by cellular and environmental factors such as by product of cellular respiration, synthesized by enzyme systems, exposure to ionizing radiation, pesticides, pollution, and heavy metals. Antioxidant defense system contains glutathione-S-transferase (GST), catalase (CAT), glutathione peroxidase (GSH-Px), glutathione (GSH), proteins and vitamins. They can inactive the harmful effects of ROS. The body produces more antioxidant enzymes in order to eliminate of ROS damage (Frei, 1999; An et al., 2008; Aksu et al., 2016; 2017).

Sperm characeristics are important for fertilization and hatching success in aquaculture and aquatic life (Kutluyer et al., 2015; Kocabaş et al., 2019). Poor sperm quality might be associated with extinction or loss of populations due to reducing productivity (Kutluyer et al., 2016). To our knowledge, there are no reports about the effect of habitat on oxidative stress biomarkers in spermatozoa of Çoruh trout. Only a study about comparison of oxidant and antioxidant status of spermatozoa in trout species (Salmo rizeensis, Salmo coruhensis, Oncorhynchus mykiss) has been performed in wild by Kutluyer et al. (2018). In this framework, in this study, oxidant and antioxidant status were compared in wild and farmed Çoruh trout (S. coruhensis) spermatozoa.

\section{Materials and Methods \\ Experimental design}

For sperm collection, mature Çoruh trout males (+2 year old, $n_{\text {wild: }} 12,23.58 \pm 1.83 \mathrm{~cm}$, $123.66 \pm 24.03 \mathrm{~g}, \mathrm{n}_{\text {farm: }} 12,23.30 \pm 1.86 \mathrm{~cm}$, $131.71 \pm 43.90 \mathrm{~g})$ were obtained from Uzungöl Stream (Trabzon, Turkey) and Fish Production Station (Meryemana, Trabzon). Before stripping, anesthetizing the males was realized with Benzoacaine $\quad\left(50 \quad \mathrm{mg} . \mathrm{I}^{-1}\right)$. Sperm samples contaminated by feces, urine, mucus, blood or water were disused in experiments. Sperm was stripped with abdominal massage to tubes $(50 \mathrm{ml})$ and kept at $4{ }^{\circ} \mathrm{C}$ until use.

\section{Measurement of lipid peroxidation and the antioxidants}

The centrifugation of sperm sample was made at $3000 \times g$ at $4^{\circ} \mathrm{C}$ for $15 \mathrm{~min}$ and homogenization of the pellet in an ice bath was performed with the $1.15 \% \mathrm{KCl}$. MDA levels $\left(\mathrm{nmolg}^{-1}\right.$ sperm cells) was measured by the method of Placer (1966). The SOD enzyme activity (U/mg protein) was assayed by the methot of Sun et al. (1988). The CAT activity (as $\mathrm{kg}^{-1}$ protein) was assessed using the method of Aebi (1984). The GSH-Px activity ( $\mathrm{Ug}^{-1}$ protein) was determined according to the method of Matkovics et al. (1988). The concentration of reduced glutathione ( $\mu \mathrm{molg}^{-1}$ sperm cells) was assessed according to Chavan et al. (2005). Protein was determined with bovine serum albumin (BSA: standard) by the method of Lowry et al. (1951).

\section{Statistical analysis}

Data obtained from measurements are given as the mean \pm standard deviation. Differences among treatments for enzymatic values were compared by independent samples t-test. The Kolmogorov-Smirnov two-sample test was used to compare the different groups. Data were analyzed using SPSS 14.0 software. A minimum significance level of $P<0.05$ was accepted.

\section{Results and Discussion}

Levels of MDA, SOD, GSH, GSH-Px and CAT are given in Table 1. Our data indicated that SOD, CAT and GSH (P>0.05), MDA and GSH-Px levels $(P<0.05)$ were low in wild compared to farmed fish spermatozoa.

Table 1. MDA, GSH levels and SOD, GSH-Px, CAT activities of wild and farmed Çoruh trout (Salmo coruhensis) spermatozoa

\begin{tabular}{lccc}
\hline Parameters & Wild & Farmed & P values \\
\hline MDA (nmol/g cell) & $2.49 \pm 0.12$ & $6.96 \pm 0.10$ & $0.003^{*}$ \\
SOD (U/mgprotein) & $0.44 \pm 1.25$ & $0.51 \pm 2.28$ & 0.688 \\
GSH ( $\mu$ mol/g cell) & $0.18 \pm 4.01$ & $0.27 \pm 2.37$ & 0.230 \\
GSH-Px (U/g protein) & $42.89 \pm 0.61$ & $61.22 \pm 0.13$ & $0.045^{*}$ \\
CAT (k/g protein) & $15.21 \pm 4.69$ & $18.88 \pm 2.66$ & 0.331 \\
\hline
\end{tabular}

*: The same raws shows significant differences among proportions $(\mathrm{P}<0.05)$.

MDA: malondialdehit, SOD: süperoksit dismutaz, GSH: glutatyon, GSH-Px: glutatyon peroksidaz, CAT: katalaz.

Physiology and behaviour of fish are influenced by environmental factors (e.g. temperature, hardness, salinity, $\mathrm{pH}$, pollutants, and habitat) (Vinagrea et al., 2012). In particular, habitat and culture environment are versatile for aquatic organisms due to affect each stage of life cycle (egg, larvae, juvenile and adult) and can also affect a variety of parameters including growth, 
improvement of feeding performance, feed intake, physiology of fish and stress (Gleyzer, 1983; Rotllant et al., 2003; Barcellos et al., 2009; Ebrahimi, 2011). There are no comparative studies on the effect of habitat on oxidant and antioxidant status of Çoruh trout spermatozoa. However, oxidant and antioxidant status of seminal plasma and spermatozoa has been compared in several fish species (Shaliutina-Kolesova et al., 2013; Dzyuba et al., 2016; Kocabaş and Bascinar, 2016; Kutluyer et al., 2015, 2016, 2018). In light of the above research we have examined the levels of the antioxidants SOD, CAT, GPX, GSH as well as lipid-peroxidation levels in spermatozoa of wild and farmed Çoruh trout in the present study. Overall, we demonstrated differences in the physiological response of fish spermatozoa due to produce Reactive Oxygen Species (ROS) under stress condition.

The presence of MDA (Malondialdehyde) being the oxidative damage products in lipid peroxidation indicates oxidative stress in spermatozoa (Saliu and Bawa-Allah, 2012). Spermatozoa are highly sensitive to lipid peroxidation (LPO) due to be lack protective cytoplasmic enzymes in membrane structure and to have polyunsaturated fatty acids (PUFA) at high concentrations ( $\mathrm{Li}$ et al., 2010). Present results indicated that the highest level of MDA concentration was in farmed fish, which means that habitat stress affects the cellular response of fish spermatozoa facing ROS. In this study, SOD, CAT, GSH-Px and GSH antioxidant levels were high level in farmed fish spermatozoa. The reason of this stiutiation can be reducing oxyradicals production. Especially, GSH-Px being one of oxidative defensive enzymes was significantly high level in farmed trout due to for the neutralization of ROS and protection from lipid peroxidation (Aitken and Roman, 2008). Our results showed that CAT activity was slightly low level in wild. Our data demonstrated that GSH was higher level in farmed trout. Reduced glutathione being antioxidant agents provide protection structure of cell againist lipid peroxidation (Olakolu et al., 2012). In present study, superoxide dismutase activity was highest level in farmed trout compared to wild trout. We suggested that the antioxidant response to stress can be explained by habitat differences. Habitat might be caused free radical generation in spermatozoa. The present results may be due to reduced stress in wild due to be their natural habitat. In addition, reason of the stress can be unsuitable feed in fish farming (Henrotte et al., 2010).

\section{Conclusion}

Consequently, habitat affected to the antioxidant status of Çoruh trout spermatozoa. It is recommended that feeds and feeding protocols could be optimized under rearing conditions. The knowledge will provide to benefit aspects related to fish production and farming.

\section{References}

Aebi, H. 1984. Catalase in vitro. Methods in Enzymology, 105: 121-126.

Aitken, R.J., Roman, S.D. 2008. Antioxidant systems and oxidative stress in the testes. Oxidative Medicine and Cell Longevity, 1(1): 15-24.

Aksu, Ö., Cikcikoğlu Yildirim, N., Danabaş, D., Yildirim, N. 2017. Biochemical impacts of the textile dyes Remazol Brillant Blue $\mathrm{R}$ and Congo red on the crayfish Astacus leptodactylus (Decapoda, Astacidae). Crustaceana, 90(13): 1563-1574.

Aksu, Ö., Kutluyer, F., Can, E., Erişir, M., Benzer, F. 2016. Influence of stock density on digestive enzyme activity (trypsin), heat shock protein 70 (HSP70), and oxidative stress biomarkers of narrow clawed crayfish, Astacus leptodactylus Eschscholtz, 1823 (Decapoda, Astacidae). Crustaceana, 89(10): 1193-1202.

An, R., Li, Y., Niu, X., Yu, H. 2008. Responses of antioxidant enzymes in catfish exposed to liquid crystals from e-waste. International Journal of Environmental Research Public Health, 5: 99-103.

Barcellos, L.J.G., Kreutz, L.C., Quevedo, R.M., da Rosa, J.G.S., Koakoski, G., Centenaro, L., Pottker, E. 2009. Influence of color background and shelter availability on jundia (Rhamdia quelen) stress response. Aquaculture, 288: 51-56.

Can, E., Kutluyer, F., Delihasan Sonay, F., Köse, Ö. 2012. The use of kefir as potential probiotic in Çoruh trout (Salmo coruhensis): Effects on growth performance and immunoglobulin (IgM) levels. African Journal of Biotechnology, 11: 7775-7780.

Chavan, S., Sava, L., Saxena, V., Pillai, S., Sontakke, A., Ingole, D. 2005. Reduced glutathione: Importance of specimen collection. International Journal of Clinical Biochemistry, 20: 150-152.

Dzyuba, V., Cosson, J., Dzyuba, B., Yamaner, G., Rodina, M., Linhart, O. 2016. The antioxidant system of seminal fluid during in vitro storage of sterlet Acipenser ruthenus sperm. Fish Physiology and Biochemistry, 42: 563568.

Ebrahimi, G. 2011. Effects of rearing tank background color on growth performance in 
juvenile common carp, Cyprinus carpio L.. Agriculture Journal, 6: 213-217.

Frei, B. 1999. Molecular and biological mechanisms of antioxidant action. The FASEB Journal, 13: 963-964.

Gleyzer, S.I. 1983. Possibility of color adaptation of fish vision. Journal of Ichthyology, 23: 62164.

Henrotte, E., Mandiki, R.S.N.M., Prudencio, A.T., Vandecan, M., Melard, Ch., Kestemont P. 2010. Egg and larval quality, and egg fatty acid composition of Eurasian perch breeders (Perca fluviatilis) fed different dietary DHA/EPA/AA ratios. Aquaculture Research, 41: 53-61.

Kocabas, M., Kayim, M., Can, E., Ateş, M., Kutluyer, F., Aksu, Ö. 2011a. Spotting pattern features in the brown trout (Salmo trutta macrostigma, T., 1954) population. Scientific Research and Essays, 6: 5021-5024.

Kocabaş M., Başçinar, N., Atasaral Şahin, Ş., Kutluyer, F., Aksu, Ö. 2011b. Hatching performance and yolk sac absorption of Abant trout Salmo abanticus T., 1954. Scientific Research and Essays, 6(23): 49464949.

Kocabaş, M. and Bascinar, N. 2013. The effect of salinity on spotting features of Salmo trutta abanticus, Salmo trutta fario and Salmo trutta labrax of cultured. Iranian Journal of Fisheries Science, 12: 723-732.

Kocabaş, M., Bascinar, N. 2016. Assessing stock reproductive potential of Salmo rizeensis, Salmo trutta abanticus, Salmo trutta caspius, Salmo trutta fario and Salmo coruhensis with fecundity. Austin Biology, 1: 1015.

Kocabaş, M., Kutluyer, F., Ertekin, Ö., Aksu, Ö., Başçınar, N. 2019. Improvement of sperm motility of Oncorhynchus mykiss and Salvelinus fontinalis by L-tryptophan. Systems Biology in Reproductive Medicine, Doi: 10.1080/19396368.2019.1566414.

Kottelat, M., Freyhof J. 2007. Handbook of European Freshwater Fishes. Kottelat, Cornol, Switzerland and Freyhof, Berlin, Germany, 646 pp.

Kuru, M. 2004. The last systematic status of inland fish in Turkey. Gazi University Journal of Faculty Education, 24: 1-21.

Kutluyer, F., Erisir, M., Benzer, F., Ögretmen, F., Inanan, B.E. 2015. The in vitro effect of Lambda-cyhalothrin on quality and antioxidant responses of rainbow trout Oncorhynchus mykiss spermatozoa. Environmental Toxicology and Pharmacology, 40: 855-860.

Kutluyer, F., Benzer, F., Erisir, M., Ögretmen, F.,
Inanan, B.E. 2016. The in vitro effect of cypermethrin on quality and oxidative stress indices of rainbow trout Oncorhynchus mykiss spermatozoa. Pesticide Biochemistry and Physiology, 128: 63-67.

Kutluyer, F., Kocabaş, M., Erisir, M., Benzer, F. 2018. Comparison of oxidant and antioxidant status of Çoruh trout (Salmo coruhensis), Anatolian trout (Salmo rizeensis) and rainbow trout (Oncorynchus mykiss) spermatozoa. Atatürk University Journal of Veterinary Science, 13(1): 13-18.

Li, Z., Li, P., Dzyuba, B., Randak, T. 2010. Influence of environmental related concentrations of heavy metals on motility parameters and antioxidant responses in sturgeon sperm. Chemical Biological Interactions, 188: 473477.

Lowry, O.H., Rosenbrough, N.J., Farr, A.L., Randall, R.J. 1951. Protein measurements with the folin phenol reagent. The Journal of Biological Chemistry, 193: 265-275.

Matkovics, B., Szabo, I., Varga, I.S. 1988. Determination of enzyme activities in lipid peroxidation and glutathione pathways. Laboratoriumi Diagnosztika, 15: 248-249 (in Hungarian).

Olakolu, F.C., Hassan, A.A., Renner, K.O. 2012. Lipid peroxidation and antioxidant biomarker activities as indicator of pollution in blue crab Callinectes amnicola from Lagos lagoon. British Journal of Science, 5: 47-56.

Placer, Z.A., Cusman, L.L., Johnson, B.C. 1966. Estimation of product of lipid peroxidation (malondialdehyde) in biochemical systems. Analytic Biochemistry, 16: 359-364.

Rotllant, J., Tort, L., Montero, D., Pavlidis, M., Martinez, M., Bonga, S.E.W., Balm P.H.M. 2003. Background colour influence on the stress response in cultured red porgy Pagrus pagrus. Aquaculture, 223: 129-139.

Saliu, J.K., Bawa-Allah, K.A. 2012. Toxicological effects of lead and zinc on the antioxidant enzyme activities of post juvenile Clarias gariepinus. Resources Environment, 2: 2126.

Seyhaneyildiz Can, S., Kutluyer, F., Can, E., Kayiş, Ş., Delihasan Sonay, F., Köse, Ö., Aksu, Ö., Hüsamettin, E., Yiğitoğlu, M.R. 2014. Effect of dietary kefir on the digestive and liver enzymes activities, and glucose level of Coruh trout, Salmo coruhensis (Actinopterygii: Salmoniformes: Salmonidae). Acta Ichthyologica et Piscatoria, 44: 167-170.

Shaliutina-Kolesova, A., Gazo, I., Cosson, J., Linhart, O. 2013. Comparison of oxidant and 
antioxidant status of seminal plasma and spermatozoa of several fish species. Czech Journal of Animal Science, 58: 313-320.

Sun, Y., Oberley, W.L., Li, Y. 1988. A simple method for clinical assay of superoxide dismutase. Clinical Chemistry, 34: 497-500.

Turan, D., Kottelat, M., Engin S. 2009. Two new species of trouts, resident and migratory, sympatric in streams of Northern Anatolia (Salmoniformes: Salmonidae). Ichthyological Exploration of Freshwaters, 20: 333-364.

Vinagrea, C., Madeiraa, D., Narcisob, L., Cabrala, HN., Diniz, M., 2012. Effect of temperature on oxidative stress in fish: Lipid peroxidation and catalase activity in the muscle of juvenile seabass, Dicentrarchus labrax. Ecological Indicators, 23: 274-279. 